\title{
PENERAPAN ANIMASI MACROMEDIA FLASH UNTUK MENINGKATKAN HASIL BELAJAR FISIKA PADA MATERI TEKANAN
}

\author{
Muhammad Luqman Hakim Abbas \\ IAIN Tulungagung \\ mluqman.abbas@gmail.com
}

\begin{abstract}
Abstrak
Tujuan penelitian ini adalah untuk mengetahui peningkatan pemahaman konsep siswa pada pokok bahasan tekanan. Penelitian ini termasuk dalam penelitian eksperimen dengan desain control group pre-test-post-test. Populasi dalam penelitian ini adalah seluruh peserta didik kelas VIII MTsN 4 Jombang. Sampel dalam penelitian ini adalah kelas VIII-A yang berjumlah 35 peserta didik sebagai kelas eksperimen dan VIII-B berjumlah 38 peserta didik sebagai kelas kontrol. Instrumen penelitian berupa angket media pembelajaran dan tes pemahaman konsep siswa. Pengujian hipotesis tersebut menggunakan uji-t. hasil perhitungan diperoleh thitung= 2,569 dan ttabel = 2,065 dengan taraf signifikan 0,05. Hal ini menunjukkan bahwa thitung > ttabel. Dengan demikian penerapan animasi macromedia flash berpengaruh terhadap hasil belajar fisika materi pokok tekanan.
\end{abstract}

Kata Kunci: animasi macromedia flash, hasil belajar, tekanan

\begin{abstract}
The purpose of this study was to determine the increase in students' understanding of concepts on the subject of pressure. This study was included in an experimental study with a control group pre-test-post-test design. The population in this study were all eighth grade students of MTsN 4 Jombang. The sample in this study was class VIII-A which amounted to 35 students as the experimental class and VIII-B totaling 38 students as the control class. The research instruments were in the form of learning media questionnaires and tests of students' conceptual understanding. Testing the hypothesis using the t-test. the calculation results obtained by tcount $=2.569$ and $\mathrm{t}$ table $=2.065$ with a significant level of 0.05 . This shows that tcount $>\mathrm{t}$ table. Thus the application of macromedia flash animation has an effect on the results of learning physics subject matter pressure.
\end{abstract}

Keywords: macromedia flash animation, learning outcomes, pressure

\section{PENDAHULUAN}

Fisika merupakan salah satu cabang Ilmu Pengetahuan Alam (sains) yang konsepkonsepnya banyak yang bersifat abstrak. Oleh karena itu, dalam pembelajaran fisika diperlukan suatu alat yang dapat menjembatani daya pikir peserta didik yang masih bersifat konkret agar dapat memahami konsep yang sifatnya abstrak (Abbas, 2016). Hal tersebut diperlukan mengingat pembelajaran fisika akan lebih bermakna jika aktivitas pembelajaran dimulai dari sesuatu yang bersifat konkret ke sesuatu yang lebih abstrak(Yektyastuti \& Ikhsan, 2016) . Untuk itu diperlukan keberadaan media yang menarik dalam pembelajaran. Dengan adanya media pembelajaran peserta didik akan merasa lebih termotivasi dan lebih mudah memahami konsep-konsep yang dipelajarinya (Astra, 2018; Nurohimah, H. Wahyudin M.Kom, \& M.Kom, 2014). Seperti yang dinyatakan oleh Abbas (2015) bahwa media pembelajaran dapat mempermudah dalam menyampaikan konsep-konsep fisika terutama konsep yang abstrak, sehingga nantinya didapatkan hasil belajar yang meningkat.

Berdasarkan observasi awal dan wawancara yang dilakukan peneliti di MTsN Denanyar didapatkan bahwa pada materi pokok tekanan masih didapatkan hasil belajar yang masih rendah. Data yang diperoleh seperti Tabel 1. di bawah ini: 
Tabel 1. Data Nilai Ulangan Harian Materi Pokok Tekanan

\begin{tabular}{|c|c|c|c|}
\hline No. & Kelas & Nilai rata-rata & Ketuntasan Klasikal \\
\hline 1. & VIII A & 49,09 & $57,58 \%$ \\
\hline 2. & VIII B & 52,57 & $51,43 \%$ \\
\hline 3. & VIII C & 44,41 & $47,06 \%$ \\
\hline
\end{tabular}

Dari data di atas terlihat bahwa nilai rata-rata ulangan harian materi pokok tekanan masih rendah, karena berada di bawah nilai Kriteria Ketuntasan Minimum. Nilai Kriteria Ketuntasan Minimum (KKM) MTsN Denanyar untuk mata pelajaran fisika sebesar 70 dan ketuntasan klasikalnya harus mencapai minimal $85 \%$. Rendahnya hasil belajar fisika materi pokok tekanan ini disebabkan karena pemahaman konsep peserta didik masih kurang. Peserta didik hanya menghafalkan materi dan konsep tanpa memahaminya (Sakti, Puspasari, \& Risdianto, 2012). Hal ini karena metode mengajar yang berpusat pada guru, peserta didik menjadi terbiasa hanya menerima materi secara instan tanpa memiliki kesempatan untuk mengembangkan dan memperdalam materi pelajaran (Sakti et al., 2012)

Adapun yang melatarbelakangi mengambil sekolah di MTsN Denanyar karena kebanyakan peserta didik disana prestasi akademiknya sangat rendah, khususnya bidang Ilmu Pengetahuanalam (sains) termasuk di dalamnya pelajaran fisika. Setelah dilakukan obsevasi ternyata sangat sedikit sekali guru yang memanfaatkan fasilitas yang tersedia, misalnya alat-alat laboratorium, perpustakaan dan media pendukung lainnya (Fakhri, Bektiarso, \& Supeno, 2016). Mereka kebanyakan menggunakan metode konvensional.

Berdasarkan hal tersebut diatas, perlu adanya suatu perbaikan dalam proses pembelajaran yang berlangsung sehingga nantinya dapat meningkatkan hasil belajar peserta didik. Salah satu solusi pemecahan masalah diatas adalah menggunakan media dalam proses pembelajaran (Fakhri et al., 2016; Masykur, Nofrizal, \& Syazali, 2017; Yusuf, 2015). Media pembelajaran dapat digunakan sebagai pemicu motivasi peserta didik untuk lebih bersemangat dalam belajar (Sakti et al., 2012). Banyak jenis media pembelajaran, media animasi termasuk salah satunya. Media animasi ini dapat membuat peserta didik menjadi lebih mudah dan lebih cepat dalam memahami konsep tertentu (Astra, 2018), serta media animasi dapat menanamkan konsep yang sama dengan konsep yang dimiliki para ahli, sehingga tidak menimbulkan miskonsepsi (Abbas, 2015).

Sejalan dengan Anggraeni \& Kustijono (2013) bahwa animasi dapat digunakan sebagai penunjang proses pembelajaran yang menyenangkan dan membuat peserta didik semakin tertarik dalam mempelajari suatu konsep, meningkatkan motivasi, dan meningkatkan pemahaman peserta didik pada konsep yang dipelajari. Pemanfaatan multimedia di bidang pendidikan sangat membantu pendidik dalam proses pembelajaran (Siswoyo, Desnita, \& Kurniawati, 2017). Terbukti dengan banyaknya media di bidang pendidikan. Nurohimah et al. (2014) dalam penelitiannya menyimpulkan bahwa pengembangan multimedia pembelajaran flash sangat baik digunakan untuk meningkatkan prestasi belajar peserta didik. Selain itu, penggunaan multimedia dapat meningkatkan pemahaman konsep, aktivitas, dan tingkat berpikir peserta didik (Astuti, Sumarni, \& Saraswati, 2017).

Media pembelajaran membuat kemampuan peserta didik dalam menggunakan inferensi logika menjadi lebih baik. Nurohimah et al (2014) dalam penelitiannya menyimpulkan bahwa pembelajaran menggunakan media animasi lebih efektif untuk meningkatkan prestasi belajar peserta didik. Relevansi penelitian tersebut adalah dengan penerapan penggunaan media pembelajaran animasi macromedia flash akan berdampak signifikan terhadap hasil belajar peserta didik (Fakhri et al., 2016; Yusuf, 2015). Media pembelajaran dapat membuat peserta didik lebih cepat memahami konsep yang dipelajari (Rezeki \& Ishafit, 2017).

Dalam pembuatan media animasi tersebut, peneliti menggunakan macromedia 
flash sebagai softwarenya, karena program ini merupakan perangkat lunak yang dapat membuat proses pembelajaran jadi hidup dan interaktif (Sakti et al., 2012). Pemilihan perangkat lunak ini sebagai alat pembelajaran dikarenakan dapat digunakan untuk membuat media pembelajaran yang interaktif, terutama untuk pembuatan animasi pembelajtran (Fakhri et al., 2016). Berdasarkan latar belakang di atas maka peneliti mengambil judul "Penerapan Animasi Macromedia Flash untuk Meningkatkan Hasil Belajar Fisika pada Materi Tekanan”.

\section{METODE}

Penelitian ini termasuk dalam penelitian eksperimen. Metode yang digunakan adalah metode true experimental design. Dalam penelitian ini, yang menjadi fokus adalah pengaruh penerapan animasi macromedia flash terhadap kemampuan kognitif peserta didik. Tujuan penelitian adalah untuk memperoleh informasi apakah perlakuan yang diberikan berpengaruh secara signifikan dengan cara melihat perbedaan hasil belajar antara kelompok eksperimen dengan kontrol (Sugiyono, 2012).

Penelitian ini menggunakan desain control group pre-test-post-test. Dalam rancangan penelitian ini, ada dua kelompok yaitu kelompok eksperimen dan kontrol. Kelompok eksperimen akan mendapatkan perlakuan pembelajaran dengan penerapan animasi macromedia flash, sedangkan kelompok kontrol mendapatkan pembelajaran dengan tidak menerapkan animasi macromedia flash.

Dalam penelitian ini ada 3 variabel yaitu, pertama variabel bebas dalam penelitian ini adalah penerapan animasi macromedia flash, kedua variabel terikat penelitian ini adalah hasil belajar fisika peserta didik dan yang ketiga variabel kontrol dalam penelitian ini berupa kemampuan awal, guru, materi, tujuan pembelajaran, instrumen yang digunakan, dan cara penilaian.

Populasi dalam penelitian ini adalah seluruh peserta didik kelas VIII MTsN 4 Jombang Tahun pelajaran 2018 / 2019. Sampel dalam penelitian ini adalah kelas VIII-A yang berjumlah 35 peserta didik sebagai kelas eksperimen dan VIII-B berjumlah 38 peserta didik sebagai kelas kontrol. Teknik pengambilan sampel menggunakan teknik simple random sampling atau sampel sederhana. Dikatakan simple (sederhana) karena pengambilan anggota sampel dilakukan secara acak tanpa memperhatikan strata yang ada dalam populasi itu. Dengan asumsi anggota populasi dianggap homogen (Arikunto, 2010).

\section{HASIL DAN PEMBAHASAN}

Hasil belajar peserta didik yang akan dianalisis didapatkan dari hasil tes akhir dengan jumlah soal 20 butir, dengan nilai 0 100. Rekapitulasi perhitungan rata-rata dan standar deviasi hasil belajar peserta didik dapat dilihat pada Tabel 2.

Tabel 2. Rekapitulasi Perhitungan Nilai Hasil Belajar

\begin{tabular}{|l|c|c|}
\hline \multirow{2}{*}{\multicolumn{1}{|c|}{ Kriteria }} & \multicolumn{2}{c|}{ Kelas } \\
\cline { 2 - 3 } & Eksperimen & Kontrol \\
\hline N (jumlah peserta didik) & 24 & 26 \\
\hline Rata-rata & 59,92 & 52,50 \\
\hline Standar Deviasi & 8,24 & 11,97 \\
\hline Rata- rata N-Gain & $36,88 \%$ & $29,43 \%$ \\
\hline
\end{tabular}

Dengan demikian, hasil pengukuran variabel hasil belajar fisika peserta didik untuk setiap kelompok dideskripsikan sebagai berikut.

\section{Hasil Belajar Peserta didik Kelas Eksperimen}

Dari hasil pengukuran hasil belajar peserta didik pada mata pelajaran fisika, diperoleh rata-rata $=59,92$ dan simpangan baku $=8,24$. Agar tampak lebih jelas, hasil pengukuran hasil belajar peserta didik disajikan pada diagram Tabel 3. 
Tabel 3. Distribusi Frekuensi Hasil Belajar Siswa Dengan Media Animasi Macromedia Flash

\begin{tabular}{|c|c|c|c|c|}
\hline No. & Interval & Nilai Tengah & Frekuensi Absolut & Persentase \\
\hline 1. & $40-46$ & 43 & 2 & 8,31 \\
\hline 2. & $47-53$ & 50 & 3 & 12,50 \\
\hline 3. & $54-60$ & 57 & 5 & 20,85 \\
\hline 4. & $61-67$ & 64 & 12 & 50,00 \\
\hline 5. & $68-74$ & 71 & 1 & 4,17 \\
\hline 6. & $75-81$ & 78 & 1 & 4,17 \\
\hline & Jumlah & 363 & 24 & 100,00 \\
\hline
\end{tabular}

Tabel 3 memperlihatkan bahwa sebanyak 20,81\% peserta didik memperoleh nilai di bawah rata-rata, sebanyak $20,85 \%$ memperoleh nilai di sekitar rata-rata, dan sebanyak 58,34\% peserta didik memperoleh nilai di atas rata-rata hasil belajar fisika peserta didik yang mengikuti pembelajaran dengan penerapan animasi macromedia flash. Hal ini sesuai dengan penelitian Fakhri et al. (2016) yang menyrebutkan bahwa media pembelajaran animasi dapat meningkatkan hasil belajar peserta didik. Untuk memperjelas deskripsi data tersebut, berikut ini data disajikan dalam bentuk gambar (histogram), seperti pada Gambar 1.
Berdasarkan Tabel 3 hasil belajar fisika peserta didik yang diberikan dengan penerapan animasi macromedia flash, tampak bawah frekuensi tertinggi terletak pada rentang 61-67 dan frekuensi terendah terletak pada 68-74 dan 75-81.

\section{Hasil Belajar Peserta didik Kelas Kontrol}

Dari hasil pengukuran hasil belajar peserta didik pada pelajaran fisika, diperoleh rata-rata $=52,50$ dan simpangan baku $=$ 11,97. Agar lebih jelas, hasil pengukuran hasil belajar peserta didik disajikan pada Gambar 2.

Tabel 4. Distribusi Frekuensi Hasil Belajar Siswa Tidak Menggunakan Animasi Macromedia Flash

\begin{tabular}{|c|c|c|c|c|}
\hline No. & Interval & Nilai Tengah & Frekuensi Absolut & Persentase \\
\hline 1. & $25-32$ & 28,5 & 2 & 7,69 \\
\hline 2. & $33-40$ & 36,5 & 3 & 11,54 \\
\hline 3. & $41-48$ & 44,5 & 3 & 11,54 \\
\hline 4. & $49-56$ & 52,5 & 7 & 26,92 \\
\hline 5. & $57-64$ & 60,5 & 7 & 26,92 \\
\hline 6. & $65-72$ & 68,5 & 4 & 15,38 \\
\hline & Jumlah & 291 & 26 & 100,00 \\
\hline
\end{tabular}

Tabel 4. memperlihatkan bahwa sebanyak 30,77\% peserta didik memperoleh skor di bawah rata-rata, sebanyak $26,92 \%$ memperoleh skor di sekitar rata-rata, dan sebanyak 42,30\% peserta didik memperoleh skor di atas rata-rata. Hasil belajar fisika peserta didik yang tidak menggunakan animasi macromedia flash diperoleh hasil yang kurang memuaskan. Hal ini sesuai dengan hasil penelitian Sakti et al. (2012) yang menyebutkan bahwa hasil belajar peserta didik tanpa menggunakan media animasi masih sangat kurang, karena peserta didik tidak mampu menggunakan inferensil logikanya dengan baik. Berdasarkan tabel hasil belajar fisika peserta didik yang mengikuti metode konvensional, tampak bawah frekuensi tertinggi terletak pada rentang 49-56 dan 57-64 dan frekuensi terendah terletak pada 23-32. Perbandingan grafik kedua kelas dapat dilihat pada Gambar 1. 


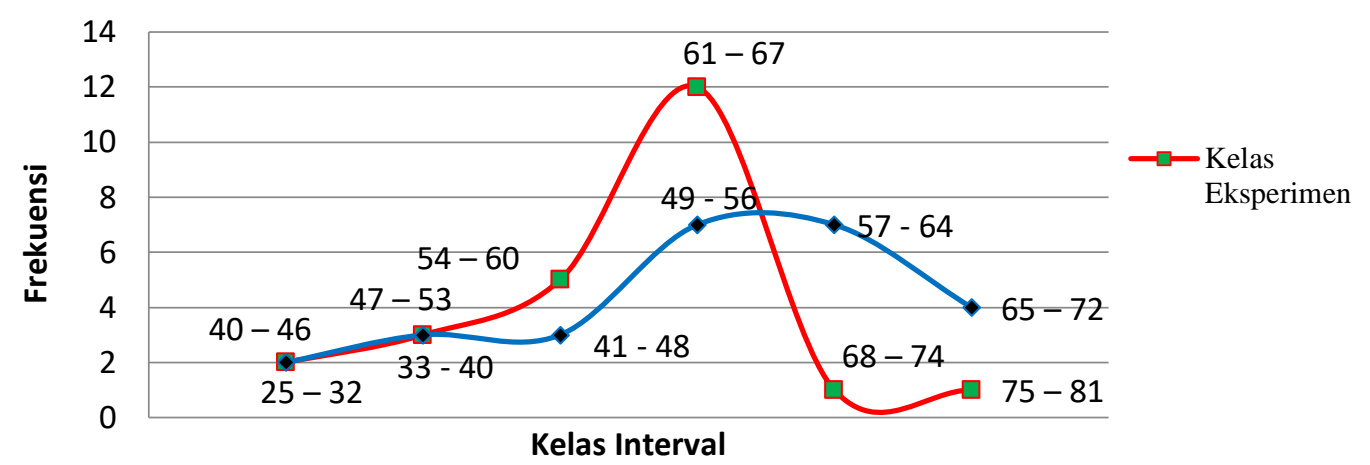

Gambar 1. Perbandingan Hasil Belajar Fisika Peserta didik Kelas Eksperimen dan Kelas Kontrol

\section{Hasil Belajar Peserta didik Setiap Sub Materi}

Materi yang diajarkan pada penelitian ini adalah Tekanan, yang terdiri dari empat sub pokok bahasan yaitu; tekanan pada zat padat, cair, gas, dan penerapan tekanan dalam kehidupan sehari-hari. Setiap sub materi dianalisis ketercapaiannya berdasarkan nilai tes awal, tes akhir, dan N-
Gain kedua kelas. Dari analisis tersebut, ternyata kedua kelas mengalami peningkatan hasil belajar di setiap sub materi. Gambar 1 . dibawah menampilkan grafik histogram peningkatan hasil belajar untuk materi pokok tekanan di kedua kelas. Perbandingan grafik peningkatan hasil belajar di setiap sub materi kedua kelas dapat dilihat pada Gambar 1.

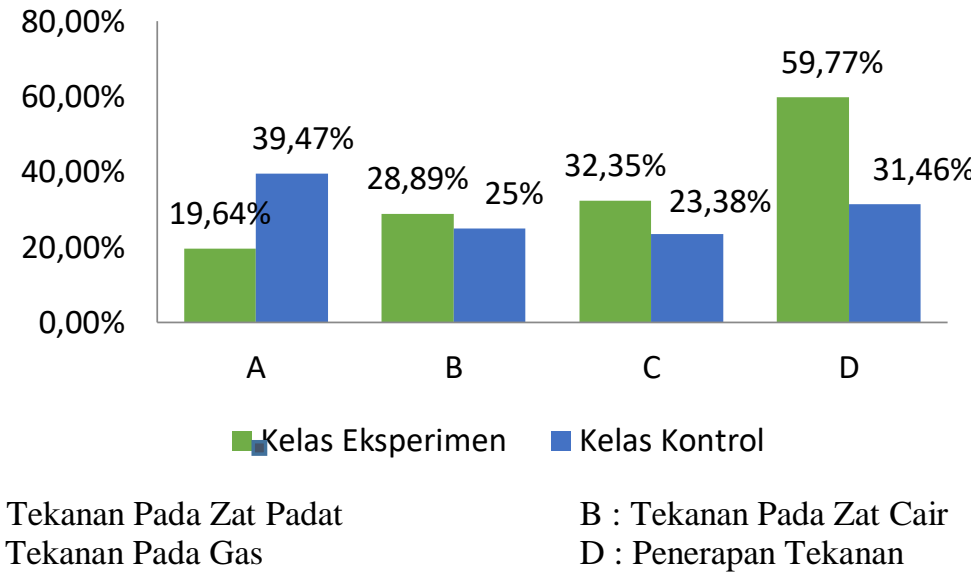

Gambar 2. Perbandingan Peningkatan Hasil Belajar Setiap Sub Materi

Dari Gambar di atas dapat dilihat bahwa perbedaan peningkatan hasil belajar di setiap sub materi kedua kelas menunjukan perbedaan tertinggi pada sub materi penerapan tekanan dalam kehidupan seharihari sebesar $28,31 \%$. Sedangkan perbedaan terkecil pada kedua kelas terjadi pada sub materi tekanan pada zat padat sebesar $19,83 \%$.

\section{Uji Hipotesis}

Uji hipotesis dianalisis menggunakan tes akhir peserta didik kelas eksperimen dan peserta didik kelas kontrol. Tes akhir dianalisis menggunakan uji-t dua pihak. Hasil analisis uji-t dari hasil belajar peserta didik (tes akhir) yang mengikuti pembelajaran dengan penerapan animasi macromedia flash dan tidak menerapkan animasi macromedia flash menunjukkan bahwa harga $t_{\text {hitung }}=2,569$ pada taraf signifikan 5\%. Harga ini lebih besar dari harga $t_{\text {tabel }}=2,064$, sehingga dapat disimpulkan bahwa $H_{o}$ ditolak dan $H_{a}$ diterima. Hal ini mengartikan bahwa penerapan animasi macromedia flash berpengaruh terhadap hasil belajar fisika materi pokok tekanan pada kelas VIII MTsN 4 Jombang. Penerapan animasi flash dapat membuat peserta didik lebih termotivasi dalam belajar (Fakhri et al., 2016), 
meningkatkan logika peserta didik (Sakti et al., 2012), sehingga dapat meningkatkan hasil belajar (Anggraeni \& Kustijono, 2013).

Pembahasan hasil penelitian yang dijelaskan pada bagian ini berupa hasil analisis deskriptif, statistik antara variabel bebas yaitu metode pembelajaran yang merupakan variabel perlakuan dan variabel terikat yaitu hasil belajar peserta didik, analisis peningkatan setiap sub materi kedua kelas dan pengamatan yang dilakukan langsung oleh peneliti selama melakukan proses belajar mengajar. Berkenaan dengan hasil penelitian ini, didapatkan bahwa terdapat perbedaan hasil belajar peserta didik yang mengikuti pembelajaran dengan media animasi macromedia flash dan tidak menggunakan animasi.

Uji normalitas dan uji homogenitas yang telah dilakukan menunjukan bahwa data tes akhir kedua kelas berdistribusi normal dan varians kedua kelas tidak homogen. Selanjutnya dilakukan uji statistik parametrik (uji-t). Uji-t yang digunakan disini adalah separated varians, karena kedua kelas memiliki jumlah peserta didik yang berbeda dan data tes akhir yang dihasilkan berdistribusi normal serta variansnya tidak homogen. Hasil uji statistik (uji-t) yang telah dilakukan, menunjukan nilai $t_{\text {hitung }}=2,569$. Harga ini lebih besar dari harga $\quad t_{\text {tabel }}=2,064$ pada taraf kepercayaan 5\%. Hal ini menunjukkan bahwa hasil belajar peserta didik yang diberikan perlakuan media animasi macromedia flash lebih baik dari pada peserta didik yang belajar dengan tidak menggunakan animasi macromedia flash. Dengan kata lain, penerapan media animasi macromedia flash berpengaruh terhadap hasil belajar peserta didik (Fakhri et al., 2016; Sakti et al., 2012).

Selain melakukan analisis pengujian hipotesis, peneliti juga ingin mengetahui sejauh mana peningkatan hasil belajar peserta didik di kedua kelas pada setiap sub materi. Perbedaan peningkatan secara umum masing-masing kelas adalah kelas eksperimen sebesar 36,88\% dan kelas kontrol sebesar 29,43\%. Data ini didapatkan setelah dilakukan pembelajaran pada kedua kelas dengan perlakuan yang berbeda. Selanjutnya dilakukan analisis terhadap data tes awal, tes akhir dan data N-gain kedua kelas. Dari hasil analisis tersebut, ternyata kedua kelas mengalami peningkatan hasil belajar di setiap sub materi tekanan. Peningkatan ini mengindikasikan bahwa penggunaan media animasi dapat meningkatkan semangat dan perhatian peserta didik untuk belajar. Selain itu, pembelajaran menggunakan multimedia interaktif juga dapat menumbuhkan motivasi belajar dan penguasaan konsep (Rezeki \& Ishafit, 2017; Sakti et al., 2012).

Peningkatan hasil belajar kelas eksperimen tertinggi pada sub materi penerapan tekanan dalam kehidupan seharihari sebesar $59,77 \%$ dan terendah pada sub materi tekanan pada zat padat sebesar 19,64\%. Untuk kelas kontrol peningkatan hasil belajar tertinggi terjadi pada sub materi tekanan pada zat padat sebesar $39,47 \%$ dan terendah pada sub materi tekanan pada gas sebesar $23,38 \%$.

Peningkatan tertinggi kelas eksperimen terjadi pada sub materi penerapan tekanan pada kehidupan sehari-hari. Sub materi ini merupakan materi yang membutuhkan visualisasi yang lebih dinamik untuk meningkatkan pemahaman konsep peserta didik. Untuk itu penggunaan animasi macromedia flash untuk membantu memvisualisasikan materi ini agar mudah dipahami oleh peserta didik dapat dikatakan efektif untuk meningkatkan pemahaman konsep (Fakhri et al., 2016).

Peningkatan $\mathrm{N}$-gain kelas eksperimen secara umum lebih tinggi daripada kelas kontrol, kecuali pada sub materi tekanan pada zat padat. Pada sub materi ini terdapat perbedaan peningkatan $\mathrm{N}$-gain pada kedua kelas, dimana peningkatan kelas kontrol lebih tinggi daripada kelas eksperimen. Hal ini dapat disebabkan oleh berbagai macam faktor seperti, kesiapan peserta didik di masing-masing kelas yang berbeda dan bentuk pembelajaran di kelas kontrol yang lebih menekankan pada pengajaran repetisi atau pengulangan latihan dan diskusi soal (Astra, 2018)

Peningkatan hasil belajar di setiap sub materi dengan menerapkan animasi macromedia flash pada pembelajaran, lebih menekankan pada pemberian materi yang dibentuk dalam ilustrasi dinamis dan bisa diproses oleh kognitif otak peserta didik. 
Sehingga menjembatani daya pikir peserta didik yang masih bersifat konkret agar dapat memvisualisasikan konsep fisika yang abstrak. Hal ini sesuai dengan penelitian Rohmani et al. (2015) yang mengatakan bahwa pembelajaran dengan multimedia interaktif dapat meningkatkan pemahaman konsep peserta didik pada $\mathrm{N}$-gain kategori sedang.

Berdasarkan prosentase perolehan skor hasil belajar peserta didik setiap sub materi pada tes awal dan tes akhir kedua kelas, diketahui bahwa prosentase terendah perolehan hasil belajar pada saat tes awal kelas kontrol terjadi pada sub materi tekanan pada gas sebesar $25,96 \%$ dan tertinggi pada sub materi penerapan tekanan pada kehidupan sehari-hari sebesar 42,95\%, sedangkan prosentase terendah setelah dilakukan tes akhir terjadi pada sub materi tekanan pada gas sebesar $43,27 \%$ dan tertinggi pada sub materi penerapan tekanan pada kehidupan sehari-hari sebesar $60,90 \%$.

Pada kelas eksperimen prosentase tertinggi perolehan skor hasil belajar setiap sub materi pada saat tes awal terjadi pada sub materi tekanan pada zat padat sebesar $41,67 \%$ dan terendahnya terjadi pada sub materi tekanan pada gas sebesar 29,17\%, sedangkan prosentase tertinggi pada saat diberikan tes akhir terjadi pada sub materi penerapan tekanan dalam kehidupan seharihari sebesar 75,69\% dan terendahnya terjadi pada sub materi tekanan pada gas sebesar $52,08 \%$. Dengan demikian, terjadi peningkatan prosentase hasil belajar setiap sub materi tekanan pada kelas kontrol dan kelas eksperimen.

Perbedaan peningkatan tertinggi untuk hasil belajar kedua kelas setiap sub materi terjadi pada sub materi penerapan tekanan pada kehidupan sehari-hari sebesar $28,31 \%$. Perbedaan peningkatan pada sub materi ini disebabkan karena pada kelas eksperimen yang diberikan perlakuan pembelajaran menggunakan animasi macromedia flash, animasi yang dibuat sangat animatif dan efektif dalam membantu peserta didik dalam memahami konsep fisika (Anggraeni \& Kustijono, 2013). Animasi yang diciptakan sangat membantu peserta didik untuk membuat gambaran mental tentang konsep yang dipelajari dan membuat konsep lebih matang dalam kognitif peserta didik (Fakhri et al., 2016). Sub materi penerapan tekanan dalam kehidupan sehari-hari ini merupakan sub terakhir dari materi tekanan yang lebih menekankan pada contoh penerapan tekanan pada zat padat, cair, dan gas dalam kehidupan sehari-hari.

Perbedaan peningkatan terendah untuk hasil belajar kedua kelas setiap sub materi terjadi pada tekanan pada zat padat sebesar $19,83 \%$. Sub materi ini adalah materi awal dalam mempelajari materi-materi lainnya. Dari analisis data yang dilakukan, didapatkan bahwa peningkatan sub materi ini lebih tinggi di kelas kontrol dibandingkan dengan kelas eksperimen. Dari hasil pengamatan, hal ini terjadi karena adanya faktor yang mempengaruhi di luar kontrol peneliti. Salah satunya adalah faktor kesiapan peserta didik yang kurang matang pada kelas eksperimen untuk menerima perlakuan menggunakan pembelajaran animasi macromedia flash. Faktor kesiapan peserta didik itu seperti pengetahuan awal (prior knowledge) tentang materi tekanan yang akan dijelaskan mempengaruhi keefektifan animasi. Anggraeni \& Kustijono (2013) mengatakan bahwa peserta didik yang tidak memiliki pengetahuan awal akan cenderung untuk lebih memperhatikan perubahan animasi yang menarik secara perseptual dibandingkan dengan perubahan yang penting dalam memahami materi.

Sebaliknya pada kelas kontrol yang diberikan perlakuan dengan tidak menggunakan pembelajaran animasi macromedia flash, faktor kesiapan peserta didik untuk memulai belajar lebih siap sehingga peserta didik dapat memulai pembelajaran dengan baik (Andriana, Djudin, \& Arsyid, 2014). Faktor lainnya juga adalah sistem belajar dengan mendiskusikan soal dalam jumlah yang cukup banyak, dan secara kebetulan juga peserta didik mendiskusikan soal yang bentuknya sama dengan soal yang diujikan. Hal inilah yang menyebabkan peningkatan hasil belajar pada sub materi tekanan pada zat padat lebih tinggi pada kelas kontrol dibanding kelas eksperimen.

Adapun sub materi lain seperti tekanan pada zat cair dan tekanan pada gas memiliki perbedaan peningkatan dengan kategori 
rendah masing-masing sebesar 3,89\% dan $8,98 \%$. Terlepas dari perlakuan kedua kelas yang berbeda, untuk sub materi ini animasi yang diberikan tetap animatif. Sedangkan pada kelas kontrol, kembali pada pembahasan awal sebelumnya, bahwa pemberian latihan soal dalam jumlah besar dapat membantu peserta didik dalam menjawab soal yang diujikan. Meskipun demikian, dari hasil penelitian menunjukan bahwa peningkatan kelas eksperimen lebih tinggi daripada kelas kontrol, walaupun perbedaan peningkatannya tidak terlalu tinggi.

Adapun kelebihan dari penelitian ini adalah membantu peserta didik memahami konsep fisika yang masih abstrak dengan cara visualisasi materi dalam bentuk animasi (Aththibby \& Salim, 2015), menambah motivasi serta perhatian peserta didik untuk belajar (Fakhri et al., 2016), dan media yang dibuat disajikan dalam tampilan yang sederhana untuk memudahkan peserta didik dalam memahami materi yang ditampilkan dalam bentuk animasi (Sakti et al., 2012). Sedangkan kekurangan penelitian ini adalah kurang siapnya peserta didik untuk belajar menggunakan animasi, dikarenakan peserta didik belum pernah mendapatkan pembelajaran menggunakan media berbasis komputer, peserta didik lebih cenderung untuk memperhatikan animasi yang ditampilkan daripada memahami materi dari perubahan animasi yang ditampilkan (Fakhri et al., 2016), dan media yang dibuat peneliti belum banyak menyisipkan animasi sesuai dengan materi yang diajarkan sehingga membutuhkan perbaikan ke depannya.

\section{DAFTAR PUSTAKA}

Abbas, M. L. H. (2015). Pengembangan Model Tes Diagnostik Three-tier Berbantuan Komputer untuk Mengatasi Miskonsepsi Siswa pada Konsep Suhu dan Kalor. DISERTASI dan TESIS Program Pascasarjana UM.

Abbas, M. L. H. (2016). Pengembangan Instrumen Three Tier Diagnostic Test Miskonsepsi Suhu dan Kalor. EdHumanistics, 01, 83-92.

Andriana, E., Djudin, T., \& Arsyid, S. B.

\section{SIMPULAN}

Berdasarkan rumusan masalah, tujuan penelitian, hasil penelitian, dan pembahasan maka dapat disimpulkan pertama penerapan animasi macromedia flash dalam pembelajaran memberikan pengaruh positif terhadap hasil belajar fisika peserta didik materi pokok tekanan pada kelas VIII di MTsN 4 Jombang serta dapat meningkatkan penguasaan konsep peserta didik dalam memvisualisasikan konsep fisika yang bersifat abstrak (Fakhri et al., 2016; Sakti et al., 2012). Kedua meningkatnya hasil belajar setiap sub materi tekanan untuk kelas eksperimen yang mendapatkan perlakuan menggunakan pembelajaran animasi macromedia flash lebih tinggi dibanding kelas kontrol yang tidak menggunakan pembelajaran dengan animasi macromedia flash. Perbedaan peningkatan hasil belajar tertinggi terjadi pada sub materi penerapan tekanan pada kehidupan sehari-hari sebesar $28,31 \%$, sedangkan terendah terjadi pada sub materi tekanan pada zat padat sebesar $19,83 \%$.

Saran yang dapat diberikan yaitu, pertama bagi peserta didik, diharapkan dapat mengembangkan motivasi untuk belajar. Kedua bagi guru, diharapkan dengan penelitian ini dapat memotivasi dan meningkatkan keterampilan dalam menggunakan media animasi macromedia flash dalam pembelajaran. Keputusan untuk menggunakan bantuan berupa animasi atau gambar tetap sebaiknya didasarkan pada pertimbangan pedagogis dan bukan pada kompetensi atau kemampuan teknologi. Bagi peneliti, diharapkan dapat menggunakan media animasi macromedia flash pada materi fisika yang lain.

(2014). Remediasi Miskonsepsi Pembiasan Cahaya Pada Lensa Tipis Menggunakan Direct Instruction Berbantuan Animasi Flash SMA. Jurnal Pendidikan Dan Pembelajaran, 3(1), 111. Retrieved from http://jurnal.untan.ac.id/index.php/jpdpb /article/view/4255.

Anggraeni, R. D., \& Kustijono, R. (2013). Pengembangan Media Animasi Fisika pada Materi Cahaya dengan Aplikasi Flash Berbasis Android. Jurnal 
Pendidikan Fisika Dan Aplikasinya, 3(1), 11-18.

Astra, I. M. (2018). Aplikasi Mobile Learning Fisika dengan Menggunakan Adobe Flash sebagai Media Pembelajaran Pendukung. Jurnal Pendidikan Dan Kebudayaan, 18(2), 174.

https://doi.org/10.24832/jpnk.v18i2.79.

Astuti, I. A. D., Sumarni, R. A., \& Saraswati, D. L. (2017). Pengembangan Media Pembelajaran Fisika Mobile Learning berbasis Android. Jurnal Penelitian \& Pengembangan Pendidikan Fisika, 3(1), 57. https://doi.org/10.21009/1.03108.

Aththibby, A. R., \& Salim, M. B. (2015). Pengembangan Media Pembelajaran Fisika Berbasis Animasi Flash Topik Bahasan Usaha Dan Energi. Jurnal Pendidikan Fisika, 3(2), 25-33.

Fakhri, M. I., Bektiarso, S., \& Supeno. (2016). Penggunaan Media Pembelajaran Animasi Berbantuan Macromedia Flash Pada Pembelajaran Fisika Pokok Bahasan Momentum , Impuls, Dan Tumbukan Kelas X SMA. Jurnal Pembelajaran Fisika, 7(3), 271277.

Masykur, R., Nofrizal, \& Syazali, M. (2017). Pengembangan Media Pembelajaran Matematika dengan Macromedia Flash. Al-Jabar: Jurnal Pendidikan Matematika, 3(1), 1177-1204.

Nurohimah, S., H. Wahyudin M.Kom, \& M.Kom, P. (2014). Perancangan Aplikasi Media Pembelajaran Fisika Untuk SMP Kelas VII Berbasis Android. Jurnal Algoritma, 11, 1-10.

Rezeki, S., \& Ishafit, I. (2017). Pengembangan Media Pembelajaran Interaktif untuk Sekolah Menengah Atas Kelas XI pada Pokok Bahasan Momentum. Jurnal Penelitian \& Pengembangan Pendidikan Fisika, 3(1), 29. https://doi.org/10.21009/1.03104.

Rohmani, Sunarno, W., \& Sukarmin, S. (2015). Pengembangan Media Pembelajaran Fisika Berbasis Multimedia Interaktif Terintegrasi Dengan LKS Pokok Bahasan Hukum Newton Tentang Gerak Kelas X SMA/MA. Jurnal Inkuiri, 4(1), 152162.
Sakti, I., Puspasari, Y. M., \& Risdianto, E. (2012). Pengaruh Model Pembelajaran Langsung (Direct Instruction) Melalui Media Animasi Berbasis Macromedia Flash Terhadap Minat Belajar Dan Pemahaman Konsep Fisika Siswa Di SMA Plus Negeri 7 Kota Bengkulu. Exacta, $\quad X(1), \quad 1-10$. https://doi.org/10.1073/pnas.141151411 2.

Siswoyo, S., Desnita, D., \& Kurniawati, H. (2017). Pengembangan Media Pembelajaran Berbasis 3D PageFlip Fisika untuk Materi Getaran dan Gelombang Bunyi. Jurnal Penelitian \& Pengembangan Pendidikan Fisika, 2(1), 97-102. https://doi.org/10.21009/1.02114.

Sugiyono. (2012). Metode Penelitian Kuantitatif Kualitatif dan $R \quad \& \quad D$. Bandung: Alfabeta.

Yektyastuti, R., \& Ikhsan, J. (2016). Pengembangan Media Pembelajaran Berbasis Android Pada Materi Kelarutan Untuk Meningkatkan Performa Akademik Peserta Didik Sma. Jurnal Inovasi Pendidikan, 2(1), 71-78.

Yusuf, A. M. (2015). Pengembangan Media Pembelajaran Berbasis Adobe Flash untuk Mata Kuliah Fisika Modern Materi Radiasi Benda Hitam. Jurnal Sains Dan Pendidikan Fisika, 2015(April), 57-71. 